\title{
A rare cause of acute abdomen: isolated necrosis of the cecum
}

\author{
Kemal Eyvaz ${ }^{1}$ (D), Hasan Ediz Sıkar² (D) Mehmet Gökçeimam²(D), Hasan Fehmi Küçük² (D), Necmi Kurt² (D) \\ ${ }^{1}$ Deparment of General Surgery, University of Health Sciences, Antalya Training and Research Hospital, Antalya, Turkey \\ ${ }^{2}$ Deparment of General Surgery, University of Health Sciences, Kartal Training and Research Hospital, İstanbul, Turkey
}

\begin{abstract}
Objective: We aimed to present a 76-year-old female patient with cecal necrosis, which is a rare cause of acute abdomen in elderly women and a variant of ischemic colitis.

Material and Methods: The patient was admitted to hospital with abdominal pain, anorexia and nausea. Physical examination, laboratory parameters and abdominal computed tomography revealed acute abdomen. We operated the patient with below umbilical midline incision. Although the pain localized to the right lower quadrant made us consider acute appendicitis as first diagnosis, other pathologies were also kept in mind for differential diagnosis.
\end{abstract}

Results: Non-occlusive cecal necrosis was determined, and terminal ileum and cecum resection and Meckel's diverticulum excision were performed. Arterial pulsation was palpated, and no sign of thrombus was found.

Conclusion: Isolated necrosis of the cecum may be due to multiple reasons. Especially in elderly female patients with predisposing factors like hypotension, sepsis, shock, drug use, vasculitis, and hypercoagulability, cecum necrosis should be kept in mind.

Keywords: Isolated necrosis of cecum, acute abdomen, ischemic colitis

Cite this article as: Eyvaz K, Sıkar HE, Gökçeimam M, Küçük $\mathrm{HF}$, Kurt N. A rare cause of acute abdomen: A rare cause of acute abdomen: isolated necrosis of the cecum. Turk J Surg 2020; 36 (3): 317-320.

\section{Corresponding Author}

Kemal Eyvaz

E-mail: drkemal07@gmail.com

Received: 26.11.2017

Accepted: 01.12 .2017

Available Online Date: 14.09 .2018

O Copyright 2020 by Turkish Surgical Society Available online at www.turkjsurg.com

DOI: 10.5152/turkjsurg.2018.1334

\section{INTRODUCTION}

Although acute intestinal ischemia is the most commonly seen ischemia in elderly patients, isolated necrosis of the cecum is a rare entity frequently encountered with diseases including chronic heart disease, systemic sepsis, hypovolemic shock, fungal infections, and rheumatoid fever $(1,2)$. Ischemic colitis is a known form of non-occlusive mesenteric ischemia resulting in a decrease in the blood flow of the colon. It may develop, in some cases, in the event of a systemic hypotension, with the use of drugs causing hypotension, and following a decrease in the heart pump and aortic and open heart surgeries. In some cases, ischemic colitis may occur spontaneously without any evidence supportive of a decrease in the mesenteric blood flow (3). Isolated necrosis of the cecum may also develop due to the congenital insufficiency of the anatomic structure of the cecum (4). Isolated necrosis of the cecum may occur following hypotension secondary to dialysis and trauma (5). This study aimed to present a case preliminarily diagnosed with and taken into operation for acute appendicitis, and then operated on for cecum and partial ileum resection due to isolated necrosis of the cecum.

\section{CASE REPORT}

A 76-year-old female patient presented to our emergency clinic with complaints of nausea and localized abdominal pain in the right lower quadrant that had started $12 \mathrm{~h}$ prior. Physical examination of the patient revealed deep tenderness, defense and rebound at McBurney's point on the right lower quadrant of the abdomen. Test and examination results were as follows: leucocyte: $16.200 / \mathrm{mm}^{3}$, blood pressure: $125 / 80 \mathrm{mmHg}$, pulse: $84 / \mathrm{min}$, fever: $37.7^{\circ} \mathrm{C}$, and there was no feature on direct abdominal graphy in the upright position. Abdominal computed tomography (CT) showed thickening on the cecum wall. It was learned from the patient's history that she had received treatment for tuberculosis 20 years ago, had undergone total 


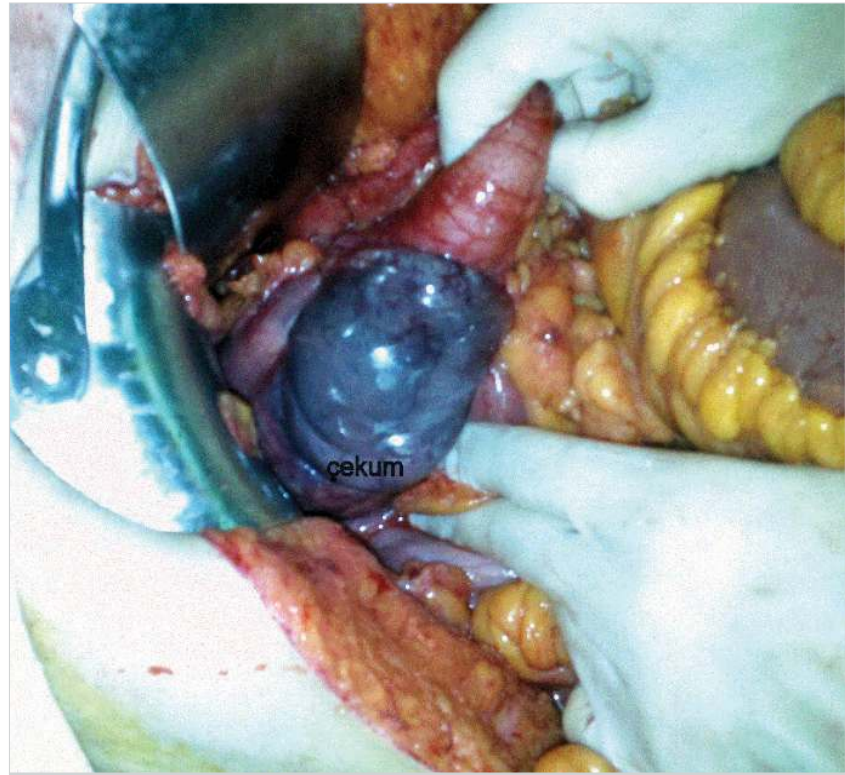

Figure 1. Necrosis in the cecum is viewed during the operation.

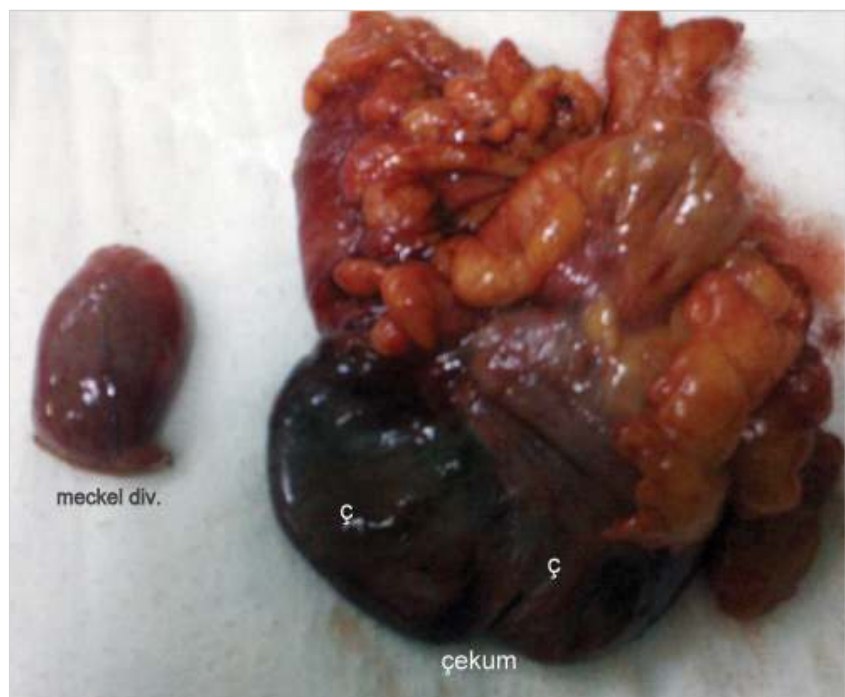

Figure 2. After the operation, the Cecum and Meckel diverticulum excision materials with terminal ileum resection are viewed.

thyroidectomy for multinodular goiter 10 years prior, and had started suffering from hypertension in recent years. With the data at hand, the patient was taken to surgery with a preliminary diagnosis of acute abdomen, primarily acute appendicitis. Since there was thickening of the cecum wall on tomography, a sub-umblical median incision was performed because another pathology could manifest itself, and it was observed that cecum necrosis was present (Figure 1). It was seen that the appendix was normal and also, there was Meckel's diverticulum, $5 \mathrm{~cm}$ in length and $65-70 \mathrm{~cm}$ proximal to the ileocecal valve. Cecum and $10 \mathrm{~cm}$ distal ileum resections were performed on the patient (Figure 2). End-to-side anastomosis was performed between the

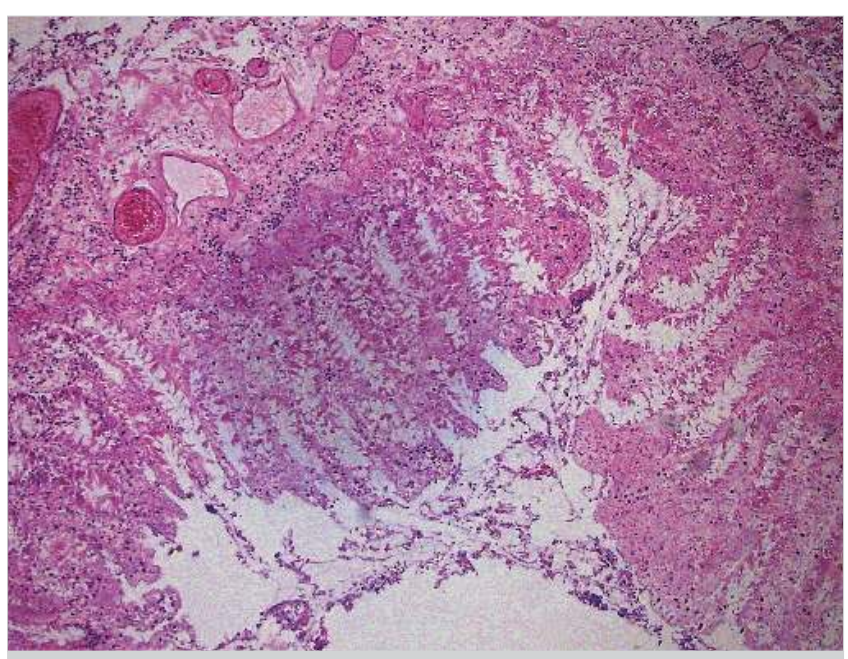

Figure 3. Ischemic areas are viewed as a result of the pathological examination of the removed material.

ileum and the ascending colon. Excision of the Meckel's diverticulum was done at the same session. The section excised was sent to pathology. Pathological examination resulted in the diagnosis of ischemic colitis (Figure 3).

\section{DISCUSSION}

Intestinal ischemia is particularly important in elderly patients. It is investigated in two groups as occlusive and non-occlusive (6). Occlusive (obstruction) conditions are investigated as obstructions related to the obstruction of major arteries, venous obstructions, obstructions due to small arterial disease, and mechanical intestinal obstructions. Obstruction of major arteries occur due to embolism, thrombus, and vein ligation. Small artery obstructions develop in patients with diabetes mellitus, vasculitis or those having received radiotherapy. Intestinal ischemia can occur due to distal tumors and the effect of sigmoid volvulus. Rarely, it can also develop as a result of the obstruction of venous flow due to hypercoagulability, pancreatitis, and portal hypertension (6).

In non-occlusive ischemic colitis, the most important factor is shock. It is believed that in case of a shock, mesenteric vasoconstriction occurs in order to provide sufficient blood flow to vital organs like the brain, kidneys, heart, and liver and disrupts feeding in the splanchnic area and result in intestinal ischemia. Isolated necrosis of the cecum is a form of acute intestinal ischemia.

Isolated necrosis of the cecum is a rarely seen surgical acute abdomen manifesting itself with complaints such as abdominal pain, nausea, and diarrhea. Physical examination may detect tenderness in the lower right abdominal region on palpation, and sometimes local or general rebound and distention signs may be found. In laboratory test, leucocyte elevation can be generally determined as $10.000-20.000 / \mathrm{mm}^{3}$. Due to the fact that it is mostly seen in the elderly population, it is understood 
from the literature that abdominal computed tomography is requested considering cecum carcinoma and that these elderly patients are taken into surgery with a preliminary diagnosis of acute appendicitis or cecum tumor $(3,7,8)$.

Methods such as ultrasonography, abdominal tomography, colonoscopy, colon graphy, occult blood in stool, direct abdominal graphy on standing position, electrocardiography, and chest $X$-ray can be used in diagnosis. Schuler et al. have preliminarily diagnosed two elderly patients aged 71 and 85 out of five cases with cecum carcinoma using abdominal CT and colonography and taken them to surgery, and their pathology results have yielded cecum necrosis (3). Thickening of the cecum wall on computed tomography is significant. In the evaluation of the aforementioned two cases, thickening of the cecum wall and a 3-4-cm filling defect on colonography were observed, and thus the cases were taken to surgery.

Fungal infections are one of the factors causing isolated necrosis of the cecum. Phycomycosis (mucormycosis) primarily involves the stomach and then the colon, cecum and terminal ileum respectively $(1,9)$. Calle and Klasky have published 14 cases in the literature (9). In almost all cases, uncontrollable diabetes mellitus, lymphoma, malnutrition, cirrhosis, gastroenteritis, antibiotic and steroid use, anemia, uremia, radiation therapy, and wounds with large tissue damage as in large burns that disrupts the immune system have been established. Treatment of this type of cases has unfortunately been fatal (9).

Although ischemic colitis leading to isolated necrosis of the cecum can involve all parts of the colon, it mostly involves the left colon (10). Especially blood build-up of the splenic flexura located between the inferior and superior mesenteric arteries is less in this region. Again, the cecum can be insufficiently fed due to the fact that the anterior and posterior cecal arteries feeding the cecum stem out of the colic branch of the ileocolic artery without forming vascular arc and collateral circulation (4). It is known that ischemic colitis develops due to non-occlusive mesenteric ischemia. While the causes of the development of ischemic colitis cannot be found in some, it can occur secondary to systemic hypotension in the event of a shock, hypovolemia, and systemic sepsis (3). Mesenteric ischemia can occur with vasoconstriction that develops as a result of digital and catecholamine drug use (4). Isolated necrosis of the cecum may also be seen with chronic heart disease, cardiopulmonary surgery, systemic chemotherapy, and cholesterol embolization (11).

Majority of the patients with isolated necrosis of the cecum published in the literature until today are females and the average age is above $68(3,12,13)$. We would like to emphasize that our case was a 76-year-old female patient. Isolated necrosis of the cecum should be kept in mind in elderly female patients with right lower quadrant abdominal pain and in those considered to have acute abdomen. Again, in elderly female patients suffering from right lower quadrant abdominal pain, acute appendicitis, cecum diverticulitis, and cecum perforation should also be kept in mind apart from isolated necrosis of the cecum. Although abdominal CT gives sufficient information for the diagnosis of acute appendicitis, complicated diverticulitis, and cecum tumor, the thickening of the cecum wall in patients with cecum necrosis might resemble cecum tumor by clustering the terminal ileum and omentum on itself $(3,4)$. Apart from those recommending colonoscopy for the diagnosis of especially isolated necrosis of the cecum in ischemic colitis, there are those that do not recommend it due to the fact that colonoscopy may lead to transmural pressure increase and perforation by increasing intraintestinal pressure $(12,14)$. It has been reported in some cases with isolated necrosis of the cecum that colonography was performed considering the possibility of a cecum tumor and were taken to surgery with the diagnosis of cecum tumor seeing irregularities in the cecum on colonography (3).

In our case, a preliminary diagnosis of acute appendicitis was made with tests including physical examination, direct abdominal graphy on a standing position, abdominal $\mathrm{CT}$, and laboratory tests; however, the possibility of another pathology was kept in mind. It is seen in the literature that most of the cases with isolated necrosis of the cecum have been taken to surgery without further tests for acute appendicitis. Surgical treatments of the cases with isolated necrosis of the cecum right hemicolectomy, cecum resection, and partial cecum resection $(3,7,8)$.

To conclude, isolated necrosis of the cecum is a rare variant of ischemic colitis. Isolated necrosis of the cecum should be kept in mind in elderly female patients with lower quadrant pain if leucocyte is elevated, physical examination points to acute appendicitis, and thickening of the cecum wall has been detected on CT.

Informed Consent: Written informed consent was obtained from patient who participated in this case.

Peer-review: Externally peer-reviewed.

Author Contributions: Concept - K.E., N.K.; Design - K.E., N.K., H.E.S., M.G.; Supervision - K.E., N.K., H.E.S.; Materials - K.E., N.K., H.E.S.; Data Collection and/or Processing - K.E., H.F.K., H.E.S., M.G.; Analysis and/or Interpretation K.E., H.F.K., M.G.; Literature Search - H.E.S., K.E., M.G.; Writing Manuscript - K.E., N.K., H.E.S., H.F.K.; Critical Reviews - K.E., N.K., H.F.K.

Conflict of Interest: No conflict of interest was declared by the authors.

Financial Disclosure: The authors declared that this study has received no financial support.

\section{REFERENCES}

1. Elnakadi I, Mehdi A, Franck S, Roger T, Larsimont D, Pector JC. Cecal infarct: report of a case. Dis Colon Rectum 1998; 41: 1585-86. [CrossRef]

2. Landreneau RJ, Fry WJ. The right colon as a target organ of nonocclusive mesenteric ischemia. Case report and review of the literature. Arch Surg 1990; 125: 591-4. [CrossRef] 
3. Schuler JG, Hudlin MM. Cecal necrosis; infrequent variant of ischemic colitis. Report of five cases. Dis Colon Rectum 2000; 43: 708-12. [CrossRef]

4. Simon AM, Birnbaum BA, Jacobs JE. Isolated infarction of the cecum: CT findings in two patients. Radiology 2000; 214: 513-6. [CrossRef]

5. Friedell ML. Cecal necrosis in the dialysis-dependent patient. Am Surg 1985; 51:621-2. [CrossRef]

6. Bower TC. Ischemic colitis. Surg Clin North Am 1993; 73: 1037-53. [CrossRef]

7. Kıyak G, Özgün Y, Sarıaya SM, Korukluoğlu B. Isolated cecal necrosis mimicking acute appendicitis. Turk J Gastroenterol 2008; 19: 71-2. [CrossRef]

8. Perko Z, Bilan K, Vilović, K, Druzijanić N, Kraljević D, Juriicić J, et al. Partial cecal necrosis treated by laparascopic partial cecal resection. Coll Antropol 2006; 30: 937-9 [CrossRef]
9. Calle S, Klasky S. Intestinal phycomycosis (mucormycosis). Am J Clin Pathol 1966; 45: 264-72. [CrossRef]

10. Marcuson RW, Farman JA. Ischaemic disease of the colon. Proc R Soc Med 1971; 64: 1080-3. [CrossRef]

11. Kingry RL, Hobson RW $2^{\text {nd }}$, Muir RW. Cecal necrosis and perforation with systemic chemoterapy. Am Surg 1973; 39: 129-33. [CrossRef]

12. Guttormson NL, Bubrick MP. Mortality from ischemic colitis. Dis Colon Rectum 1989; 32: 469-72. [CrossRef]

13. Kaminski DL, Keltner RM, Willman VL. Ischemic colitis. Arch Surg 1973; 106: 558-63. [CrossRef]

14. Bradbury AW, Brittenden J, McBride K, Ruckley CV. Mesenteric Ischaemia: a multidisciplinary approach. Br J Surg 1995; 82: 1446-59. [CrossRef]

\title{
OLGU SUNUMU-ÖZET
}

Turk J Surg 2020; 36 (3): 317-320

\section{Akut batının nadir bir nedeni: izole çekum nekrozu}

\author{
Kemal Eyvaz ${ }^{1}$, Hasan Ediz Sıkar², Mehmet Gökçeimam² ${ }^{2}$, Hasan Fehmi Küçük² ${ }^{2}$ Necmi Kurt ${ }^{2}$
}

${ }^{1}$ Sağlık Bilimleri Üniversitesi Antalya Eğitim ve Araştırma Hastanesi, Genel Cerrahi Anabilim Dalı, Antalya, Türkiye

${ }^{2}$ Sağlık Bilimleri Üniversitesi Kartal Eğitim ve Araştırma Hastanesi, Genel Cerrahi Anabilim Dalı, İstanbul, Türkiye

\section{ÖZET}

Giriş ve Amaç: Akut batın tablosuna neden olan ve iskemik kolitin bir varyantı olup nadir görülen izole çekum nekrozlu 76 yaşındaki hastamızı literatür eşliğinde sunup yaşlı kadın hastalarda izole çekum nekrozunun akut batına sebep olabileceğine dikkat çekmek istedik.

Gereç ve Yöntem: Karın ağrısı, bulantı ve iştahsızlık nedeniyle başvuran hasta yapılan fizik muayenesi, laboratuvar tetkikleri ve görüntüleme yöntemleri sonucunda akut batın tanısı ile göbek altı median insiyonla ameliyata alınmıştır. Ağrının sağ alt kadrana lokalize olması ilk etapta akut apandisiti düşündürmüş olmakla birlikte benzer tabloya sebep olabilecek diğer patolojiler de akılda tutulmuştur.

Bulgular: Laparatomide non-oklüziv izole çekum nekrozu saptanmış olup terminal ileum + çekum rezeksiyonu ameliyatı yapılmış, ayrıca mevcut olan Meckel divertikülü eksize edilmiştir. Çekuma giden damarlar palpe edilmiş ve herhangi bir trombüs bulgusuna rastlanmamıştır. Arteriyel pulsasyon alınmıştır.

Sonuç: İzole çekum nekrozu multipl nedenlerden dolayı olabilir. Özellikle yaşlı bayan hastalarda hipotansiyon, sepsis, şok, ilaç kullanımı, vaskülit, hiperkoagülabilite gibi predispozan risk faktörleri olduğu durumlarda çekum nekrozunun olabileceğini düşünmek gerekir.

Anahtar Kelimeler: Çekum nekrozu, akut batın, iskemik kolit

DOI: $10.5152 /$ turkjsurg.2018.1334 